\title{
Distinct genetic subdivision in sympatric and sibling species of the genus Littorina (Gastropoda: Littorinidae)
}

\author{
EMILIO ROLÁN-ALVAREZ*, CARLOS ZAPATA \& GONZALO ALVAREZ \\ Departamento de Biología Fundamental, Facultad de Biología, Universidad de Santiago de Compostela, 15706 \\ Santiago, Spain
}

\begin{abstract}
The genetic structure of two sibling and sympatric species of the genus Littorina was compared using allozymic loci. The two species are biologically and ecologically well-known and mostly show similar life history characteristics. Three populations of $L$. mariae Sacchi \& Rastelli and L. obtusata (L.) were studied in the Muros-Noya Ria (Galicia, NW Spain). In addition, four microgeographical subsamples taken from one of the populations were analysed for each species. Age, sex and genotypes for nine polymorphic loci were studied in 1250 snails of both species.

L. mariae showed larger genetic population subdivision and lower heterozygosity levels for the loci studied than did L. obtusata. Heterozygote deficiencies were found in only a few cases in natural populations of both species, usually affecting the Lap-1 locus. No significant genetic differences among age or sex classes were found. These results may be explained by the lower effective population size in $L$. mariae than in L. obtusata. Known differences between these species in generation interval and population density during the winter can cause the different effective population sizes suggested. These life history characteristics appear to provide the most likely explanations for the differences in genetic differentiation and heterozygosity between the two species. A previously unknown $L$. mariae morph from exposed shores is tentatively suggested to be conspecific.
\end{abstract}

Keywords: allozymes, flat periwinkles, genetic structure, Littorina mariae, Littorina obtusata, population subdivision.

\section{Introduction}

The use of allozymes as genetic markers has made possible detailed studies of population genetic structure in many animal and plant species (Ward, 1990; Lewontin, 1991). They have been used to show that species often display different hierarchical levels of population subdivision (Johnson \& Black, 1991; Wolf, 1991), constraining or predisposing adaptive evolution (Wright, 1978; Slatkin, 1987). Moreover, undetected population structure can invalidate experimental field hypotheses. Thus, the study of a species' genetic structure is a necessary preliminary step in understanding the evolutionary potential of any taxon.

The degree of genetic subdivision (genetic structure) in any species can be described as an equilibrium between the evolutionary factors that promote genetic

*Correspondence: Unidad de Genética, Biológicas Módulo A201, Universidäd Autónoma de Madrid (Cantoblanco), 28049 Madrid, Spain. cohesiveness and the factors that promote genetic differentiation; with some factors, for example natural selection, the influence can be in either direction (Nei, 1987; Slatkin, 1987). Some authors have also emphasized the factors extrinsic to the organism (biotic and abiotic) that can influence the degree of genetic relatedness among populations (Johnson \& Black, 1991). It is desirable that any experiment designed to find the relative importance of the different factors includes some means of controlling them, at least partially. Comparative studies, among similar species with different genetic structures, have been used to infer the biological causes producing these differences (Berger, 1983; Ward, 1990). In these cases the uncontrolled factors are assumed to affect the compared species in the same way. A useful group for this kind of study is the North-Atlantic littorinids (Mollusca: Gastropoda), as they often have different genetic structures and they have been well-studied biologically and ecologically. In most cases the degree 
of population differentiation is related to the degree of gene flow among populations, inferred from dispersal capabilities or breeding systems (Berger, 1983; Janson, 1987a; Ward, 1990). This relationship may, however, be rather inaccurate in some species (Berger, 1977). The level of population subdivision is also sensitive to historical phenomena, such as bottlenecks, founder events (Berger, 1977; Janson, 1987b; Knight et al., 1987) and selection (Berger, 1983; Johannesson \& Johannesson, 1989). However, other relationships are not easily found in comparative studies because of the difficulty in using closely related species with comparable life history characteristics (Wolf, 1991). Here, the population genetic structures were compared, geographically and microgeographically, in two wellknown sibling species living sympatrically in the same habitat.

Littorinid species which have direct development usually present more taxonomical problems than species having planktonic stages (Ward, 1990). On exposed Galician shores an unusual form of Littorina mariae morph has been found living on Mastocarpus stellatus (Rolán \& Templado, 1987). The transition between the exposed and the typical form occurred abruptly in the area studied, suggesting a possible case of overlapping of valid species. In this study, these two forms were studied genetically for 10 allozymic loci to clarify their taxonomic status.

This paper reports different genetic structures in sympatric populations of the two sibling species $L$. mariae and $L$. obtusata. The facts known of the biology and ecology of these species allow suggestions to be made of the main causes of genetic differences between them. Moreover, results of the analysis of one sample of the L. mariae exposed morph from Galicia supports the suggestion that it is conspecific, perhaps an ecotype of this species.

\section{Materials and methods}

\section{Species studied}

Littorina mariae and L. obtusata are two sibling species of North-Atlantic littorinids living in the Fucaceae belt of intertidal zones (Fretter \& Graham, 1980). Some reproductive characteristics (Fretter \& Graham, 1980; Reid, 1990) as well as some allozymic loci (Morris, 1979; Zaslavskaya et al., 1992) can be used to distinguish the two species. They are dioecious and have direct development with crawling juveniles hatching from egg masses attached to seaweeds (Fretter \& Graham, 1980). On Galician shores both species are found sympatrically (mainly on Fucus vesiculosus), although $L$. mariae prefers mid to lower intertidal zones whereas $L$. obtusata prefers mid to upper ones
(Rolán \& Templado, 1987; Rolán-Alvarez, 1992). They show similar life history characteristics, although some differences are known: L. mariae is an annual species that feeds mainly on micro-epiphytes growing on seaweeds (Fretter \& Graham, 1980; Williams, 1990,1992 ) whereas $L$. obtusata survives between 2 and 10 years feeding directly on seaweeds (Fretter \& Graham, 1980; Sergievsky, 1985). In addition, $L$. mariae is usually less affected by parasites and more affected by intertidal predators and other competing grazers than $L$. obtusata, which resists more stressful physical conditions during low tidal periods (Fretter \& Graham, 1980; Williams, 1990, 1992).

\section{Sampling}

To find the geographical distribution of both species more than 32 samplings were carried out in the Ria of Muros-Noya (Fig. 1). Following this, three populations representative of the distribution of the two species in the Ria were selected: ABE (Abelleira, October 1989), AGU (Aguieira, October 1989) and PLB (Punta-LaxeBrava, May 1990) (Fig. 1). Around 100 adult snails from the smallest possible area of Fucus were sampled in each population. This meant sampling areas of 1-2 $\mathrm{m}^{2}$ for most cases, but about $50-200 \mathrm{~m}^{2}$ in two samples of L. mariae (AGU and PLB, respectively). In the PLB population both species were sampled without overlapping; L. mariae was found on Mastocarpus stellatus whereas L. obtusata was found on F. vesiculosus.

Four microgeographical samples of both species were taken from the Abelleira population (July 1990). These snails were sampled over Fucus areas of about $150 \mathrm{~m}^{2}$. Copulating pairs and, around them on the same or contiguous seaweeds, noncopulating snails were sampled in each area. This design was used in an attempt to study sexual selection in nature (RolánAlvarez et al., unpublished data). Briefly, the noncopulating snails represented more than 77 per cent of the snails from the total population in L. mariae and more than 95 per cent in L. obtusata. The noncopulating subsamples of this later experiment were used to analyse the microgeographical genetic structure of these species. The species were classified according to shell characters in the field and this was later verified in the laboratory.

\section{Variables and electrophoretic methods}

Sex and age classes, and genotypes for 10 allozymic loci, were recorded for 1250 individuals of the two species. Three sex classes were used: males (M), females (F) and immature snails (I) (Fretter \& Graham, 


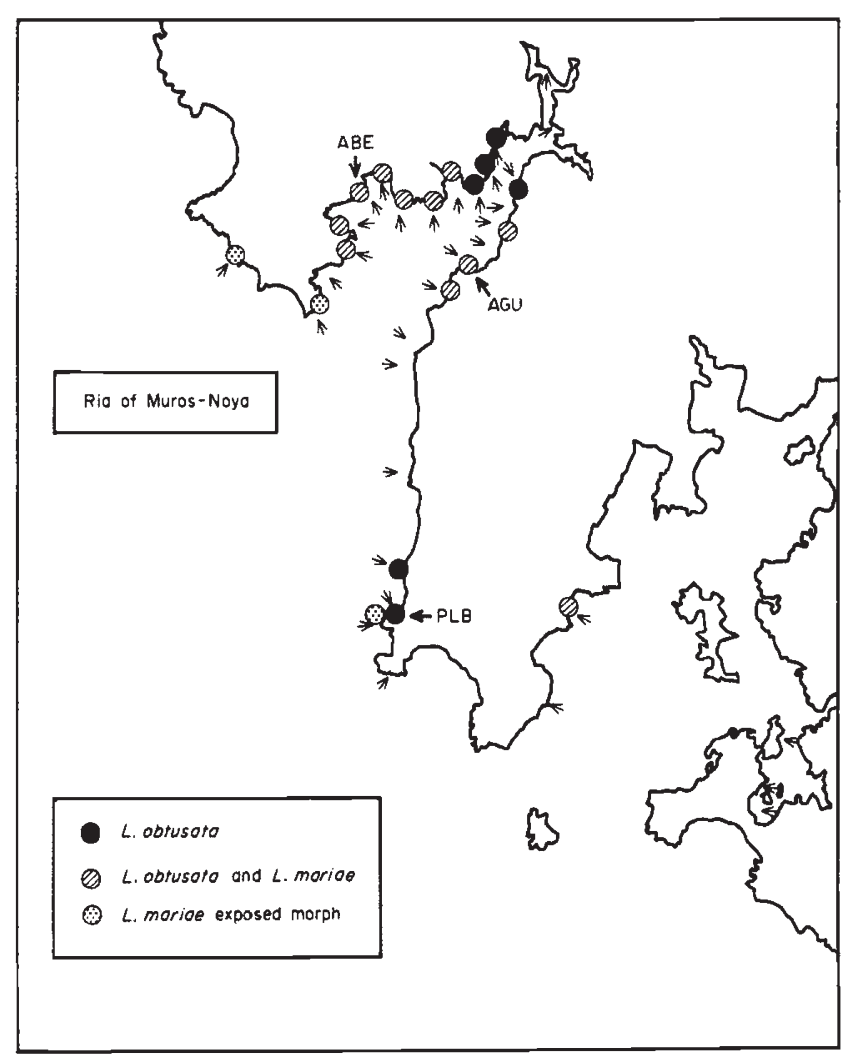

Fig. 1 Distribution of Littorina mariae and L. obtusata in the Ria of Muros-Noya. Arrows represent sampling areas.

1980; Reid, 1990). The two age classes used were based on the qualitative differences that can be observed during the shell growth: old $(\mathrm{O})$ and young (Y) (Goodwin \& Fish, 1977; Fretter \& Graham, 1980).

Specimens were stored at $-40^{\circ} \mathrm{C}$ or $-70^{\circ} \mathrm{C}$ prior to dissection and electrophoresis. The posterior soft parts of each snail were homogenized in proportional volumes of $0.1 \mathrm{M}$ Tris $/ \mathrm{HCl}(\mathrm{pH} 7.0)$. Electrophoresis was carried out using horizontal starch Sigma gels (12.5-14 per cent). The buffer systems used were continuous Tris-EDTA-borate (TEB) and Tris-EDTAmaleate (TEM) modified from Quesada (1992). Seven stain systems and ten loci were examined following Morris (1979) and Quesada (1992): phosphoglucose isomerase (E.C.5.3.1.9; Pgi), phosphoglucose mutase (E.C.5.4.2.2; Pgm), mannose phosphate isomerase (E.C.5.3.1.8; Mpi), esterases (E.C.3.1.1.1; Es-2 and Esc), arginine phosphokinase (E.C.2.7.3.3; Ark and Arkc), aminopeptidase (E.C.3.4.13.-; Glycyl-L-leucine; $A p$ ), leucine aminopeptidase (E.C.3.4.11.-; Lap-1 and Lap-2). Loci and alleles were labelled according to their electrophoretic mobilities (Ward \& Warwick, 1980).

\section{Statistical analysis}

Variation in allelic and genotypic frequencies among samples for each locus and species were analysed using $\chi^{2}$ homogeneity tests. A pseudoprobability $\chi^{2}$ homogeneity test was employed when low sample size within cells (less than five) was expected (Zaykin \& Pudovkin, 1993). Nei's unbiased heterozygosity index $\left(H_{\mathrm{e}}\right)$ was used to describe allozymic polymorphism in the genetic markers studied (Nei, 1987). Two $F$ indices were used to indicate departure from Hardy-Weinberg expectations: the Wright's $F$ and the Robertson \& Hill (1984) $F^{\prime}$ indices. The $F$ statistic was calculated using the Blosys programme (Swofford \& Selander, 1981), and the pseudoprobability test for $D(-F)$ (Zaykin \& Pudovkin, 1993) was used to obtain its significance. A BASIC program was used to calculate $F^{\prime}$ and its particular statistical test (Quesada et al., 1992). A modification of the Bonferroni multitest correction was employed when many tests were carried out simultaneously (Rice, 1989).

The fixation $F$ indices were used to study the genetic structure in each species, using the Blosys program (Swofford \& Selander, 1981). This analysis decomposes the Hardy-Weinberg deviation for every locus into three components, $F_{\mathrm{IS}}, F_{\mathrm{ST}}$ and $F_{\mathrm{IT}}$ (Wright, 1978; Nei, 1987). These estimators need fewer assumptions than alternative estimators (Nei, 1987). A pseudoprobability homogeneity $\chi^{2}$-test (Zaykin \& Pudovkin, 1993) was used to test $F_{\mathrm{ST}}$ estimates. Comparisons among populations were made with Nei's unbiased genetic identity. The bootstrap confidence interval for each combination of pairs was also calculated (D. V. Zaykin \& A. N. Tatarenkov, personal communication). An UPGMA dendogram is presented for the genetic distances of the samples involved.

\section{Results}

\section{Geographical analysis}

The distribution of $L$. mariae and $L$. obtusata in the Ria of Muros-Noya is shown in Fig. 1. Both species have similar geographical distributions and appear sympatrically in most populations; however, in the more exposed shores $L$. mariae predominates whereas in the more sheltered ones $L$. obtusata appears alone. In addition, no significant differences were found in the distribution of the sexes between samples of each species. Furthermore, the male/female ratio did not differ significantly from one in any sample. However, significant differences with respect to the frequency of age classes among samples were found (Table 1).

Allozyme frequencies of the polymorphic loci were scored for each species from the Ria of Muros-Noya 
(tables available from authors). Arginine kinase cathodal $(A r k-c)$ was monomorphic in both species whereas seven loci were polymorphic in $L$. mariae and nine in $L$. obtusata. One diagnostic locus $(A p)$ and two loci with substantial differences ( $M p i$ and $A r k$ ) were found between these two sibling species. $L$. mariae presented a mean Nei unbiased heterozygosity $\left(H_{\mathrm{e}}\right)$ of $0.108( \pm 0.036)$ and $1.7( \pm 0.22)$ alleles per locus for the 10 loci whereas L. obtusata showed a mean $H_{\mathrm{e}}$ of $0.216( \pm 0.049)$ and $1.97( \pm 0.03)$ alleles per locus. The heterozygosity per locus and population was significantly different between the two species in a Wilcoxon-Mann-Whitney test $\left(U=196, n_{1}=27\right.$, $\left.n_{2}=27, P<0.01\right)$. However, this result may not be representative of the genome of each species because of the low number of loci employed in the study. Allelic frequency differences between males and females or old and young snails were analysed in each species for most loci and samples (except $L$. mariae PLB). No gene frequency differences between sex or age classes among samples were found after Bonferroni multitest corrections.

Estimators of the Hardy-Weinberg deviations are shown in Table 2. The $F$ and $F^{\prime}$ statistics show similar results, with only a few significant $F$ or $F^{\prime}$ estimates in these samples without Bonferroni corrections: five and six cases in 38 tests, respectively. The alternative statistical tests (for $F$ or $F^{\prime}$ ) gave similar results, even if the pseudoprobability test was slightly more conservative (see Table 2). The significant cases may not be randomly distributed as most were heterozygote deficiencies and appeared at the Lap- 1 locus. However, using the Bonferroni corrections only two $F$ or $F^{\prime}$ estimates were significant: at the Lap-1 locus in the samples of both species from Abelleira (see Table 2).

The $F$ fixation indices of both species, in the samples studied, are shown in Table 3 . The $F_{\text {IS }}$ index represents an estimate of the mean $F$ or $F^{\prime}$ values per locus for the samples analysed. Thus, it gave similar results to the mean values of $F$ or $F^{\prime}$ shown in Table 2 . However, a significant positive association between the $F_{\text {Is }}$ values per locus of each species was observed, using a Kendall tau test $(\tau=0.809, n=7, P<0.05)$.

Both $L$. mariae and $L$. obtusata showed substantial genetic subdivision in the Ria of Muros-Noya, with distinct loci in each species contributing to the population differentiation (Table 3). Interestingly, L. mariae (mean $F_{\mathrm{ST}}=0.085$ ) showed more pronounced differentiation than L. obtusata (mean $F_{\mathrm{ST}}=0.037$ ). All the $F_{\mathrm{ST}}$ values were significant in $L$. mariae after Bonferroni corrections whereas only five of the nine $F_{\mathrm{ST}}$ values were significant in $L$. obtusata. Furthermore, the $L$. mariae $F_{\mathrm{ST}}$ per locus estimates were significantly greater than for $L$. obtusata, using the Wilcoxon-Mann-Whitney test $\left(U=12.5, \quad n_{1}=7\right.$, $\left.n_{2}=9, P<0.05\right)$. However, one sample of $L$. mariae (PLB) comprised an atypical morph adapted to a completely distinct habitat. This population alone would be able to explain the different genetic subdivision between both species. A new test was devised to examine this possibility: the fixation $F_{\mathrm{ST}}$ index was compared in both species excluding the PLB samples.

Table 1 Percentage of sex and age classes in Littorina mariae and L. obtusata from the Ria of Muros-Noya

\begin{tabular}{|c|c|c|c|c|c|c|c|c|}
\hline & \multicolumn{4}{|c|}{ L. mariae } & \multicolumn{4}{|c|}{ L. obtusata } \\
\hline & $\mathrm{ABE}$ & AGU & PLB & $\chi^{2}$ & $\mathrm{ABE}$ & $\mathrm{AGU}$ & PLB & $\chi^{2}$ \\
\hline \multicolumn{9}{|l|}{ Sex } \\
\hline $\mathbf{M}$ & 54.8 & 47.5 & - & & 56.8 & 44.2 & 38.0 & \\
\hline $\mathbf{F}$ & 40.4 & 49.5 & - & & 43.2 & 52.5 & 62.0 & \\
\hline I & 4.8 & 3.0 & - & & - & 3.3 & - & \\
\hline$(N)$ & 104 & 99 & & 1.45 & 95 & 120 & 50 & 2.97 \\
\hline \multicolumn{9}{|l|}{ Age } \\
\hline $\mathrm{O}$ & 85.0 & 87.1 & 0 & & 96.9 & 74.1 & 98.0 & \\
\hline Y & 14.9 & 12.9 & 100 & & 2.9 & 25.8 & 2.0 & \\
\hline$(N)$ & 107 & 101 & 103 & $238.21^{* * *}$ & 97 & 116 & 50 & $31.28^{* * *}$ \\
\hline
\end{tabular}

(M) males, (F) females and (I) immature snails; $(\mathrm{O})$ old and ( $\mathrm{Y}$ ) young snails; (ABE) Abelleira, (AGU) Aguieira and (PLB) Punta-Laxe-Brava. The frequencies of sex and age classes between populations were compared using pseudoprobability $\chi^{2}$ homogeneity tests (Zaykin \& Pudovkin, 1993). $(N)$ is sample size.

*** $P \leqslant 0.001$. 
Table 2 Estimators of deviations from Hardy-Weinberg proportions per locus in three populations of Littoria mariae and $L$. obtusata

\begin{tabular}{|c|c|c|c|c|c|c|c|c|c|}
\hline \multirow[b]{2}{*}{ Locus } & & \multicolumn{3}{|c|}{ L. mariae } & \multirow[b]{2}{*}{ Mean } & \multicolumn{3}{|c|}{ L. obtusata } & \multirow[b]{2}{*}{ Mean } \\
\hline & & $\mathrm{ABE}$ & $\mathrm{AGU}$ & PLB & & $\mathrm{ABE}$ & AGU & PLB & \\
\hline$P g i$ & $\begin{array}{c}F \\
F^{\prime} \\
(N)\end{array}$ & $\begin{array}{l}-0.046 \\
-0.020 \\
116\end{array}$ & $\begin{array}{l}-0.020 \\
-0.015 \\
100\end{array}$ & $\begin{array}{l}-0.120 \\
-0.115 \\
103\end{array}$ & $\begin{array}{l}-0.062 \\
-0.050\end{array}$ & $\begin{array}{l}-0.016 \\
-0.011 \\
96\end{array}$ & $\begin{array}{l}-0.088 \\
-0.084 \\
116\end{array}$ & $\begin{array}{l}-0.064 \\
-0.054 \\
50\end{array}$ & $\begin{array}{l}-0.056 \\
-0.050\end{array}$ \\
\hline$P g m$ & $\begin{array}{c}F \\
F^{\prime} \\
(N)\end{array}$ & - & $\begin{array}{l}0.119 \\
0.070 \\
102\end{array}$ & - & $\begin{array}{l}0.119 \\
0.070\end{array}$ & $\begin{array}{l}0.026 \\
0.032 \\
87\end{array}$ & $\begin{array}{r}0.013 \\
0.017 \\
114\end{array}$ & $\begin{array}{l}0.062 \\
0.072 \\
50\end{array}$ & $\begin{array}{l}0.034 \\
0.040\end{array}$ \\
\hline$M p i$ & $\begin{array}{c}F \\
F^{\prime} \\
(N)\end{array}$ & - & - & - & - & $\begin{array}{l}0.181^{*} \\
0.142^{* *} \\
88\end{array}$ & $\begin{array}{r}0.018 \\
0.018 \\
112\end{array}$ & $\begin{array}{l}-0.030 \\
-0.060 \\
36\end{array}$ & $\begin{array}{l}0.056 \\
0.033\end{array}$ \\
\hline$E s-2$ & $\begin{array}{c}F \\
F^{\prime} \\
(N)\end{array}$ & $\begin{array}{r}0.068 \\
0.043 \\
116\end{array}$ & - & - & $\begin{array}{l}0.068 \\
0.043\end{array}$ & $\begin{array}{l}0.156 \\
0.162 \\
96\end{array}$ & $\begin{array}{l}-0.035 \\
-0.030 \\
112\end{array}$ & $\begin{array}{l}-0.075 \\
-0.066 \\
50\end{array}$ & $\begin{array}{l}0.015 \\
0.022\end{array}$ \\
\hline$E s-c$ & $\begin{array}{c}F \\
F^{\prime} \\
(N)\end{array}$ & $\begin{array}{l}-0.016 \\
-0.016 \\
111\end{array}$ & $\begin{array}{r}0.135 \\
0.140 \\
101\end{array}$ & - & $\begin{array}{l}0.059 \\
0.062\end{array}$ & $\begin{array}{l}0.080 \\
0.086 \\
94\end{array}$ & $\begin{array}{l}-0.250^{* *} \\
-0.247^{* *} \\
115\end{array}$ & $\begin{array}{l}0.114 \\
0.126 \\
50\end{array}$ & $\begin{array}{l}-0.019 \\
-0.012\end{array}$ \\
\hline Ark & $\begin{array}{c}F \\
F^{\prime} \\
(N)\end{array}$ & $\begin{array}{r}0.041 \\
0.026 \\
116\end{array}$ & $\begin{array}{l}0.095 \\
0.100 \\
100\end{array}$ & $\begin{array}{l}-0.101 \\
-0.095 \\
94\end{array}$ & $\begin{array}{l}0.012 \\
0.012\end{array}$ & $\begin{array}{l}0.080 \\
0.086 \\
96\end{array}$ & $\begin{array}{l}-0.080 \\
-0.076 \\
116\end{array}$ & $\begin{array}{l}-0.068 \\
-0.058 \\
49\end{array}$ & $\begin{array}{r}-0.023 \\
0.016\end{array}$ \\
\hline Lap-1 & $\begin{array}{c}F \\
F^{\prime} \\
(N)\end{array}$ & $\begin{array}{l}0.175^{* * *} \\
0.385^{* * *} \\
111\end{array}$ & $\begin{array}{l}0.172^{*} \\
0.160^{* *} \\
90\end{array}$ & $\begin{array}{l}-0.051 \\
-0.045 \\
83\end{array}$ & $\begin{array}{l}0.099 \\
0.167\end{array}$ & $\begin{array}{l}0.795 * * * \\
0.804 * * * \\
96\end{array}$ & $\begin{array}{c}0.226 \\
0.134^{*} \\
116\end{array}$ & $\begin{array}{l}0.027 \\
0.038 \\
50\end{array}$ & $\begin{array}{l}0.349 \\
0.325\end{array}$ \\
\hline Lap-2 & $\begin{array}{c}F \\
F^{\prime} \\
(N)\end{array}$ & $\begin{array}{l}-0.027 \\
-0.022 \\
116\end{array}$ & $\begin{array}{l}-0.128 \\
-0.117 \\
39\end{array}$ & $\begin{array}{l}- \\
-\end{array}$ & $\begin{array}{l}-0.077 \\
-0.047\end{array}$ & $\begin{array}{l}-0.064 \\
-0.056 \\
65\end{array}$ & - & $\begin{array}{l}-0.042 \\
-0.032 \\
50\end{array}$ & $\begin{array}{l}-0.053 \\
-0.044\end{array}$ \\
\hline
\end{tabular}

The significance of Wright's $F$ estimator was tested using a pseudoprobability test (Zaykin \& Pudovkin, 1993) and of Robertson and Hill's $F^{\prime}$ estimator the specific test designed for this purpose (Robertson \& Hill, 1984). The underlined asterisks represent significant cases following Bonferroni corrections. $(N)$ is sample size.

$* P \leqslant 0.05,{ }^{* *} P \leqslant 0.01,{ }^{* * *} P \leqslant 0.001$.

L. mariae showed larger population genetic differentiation (mean $F_{\mathrm{ST}}=0.052$ ) than $L$. obtusata (mean $F_{\mathrm{ST}}=0.019$ ). However, the $F_{\mathrm{ST}}$ differences between species were not significant, although they were close to being significant $\left(U=13, n_{1}=7, n_{2}=9, P=0.071\right)$. Furthermore, six of the seven $F_{\text {ST }}$ per locus estimates in $L$. mariae were significant after Bonferroni corrections whereas only three of nine $F_{\mathrm{ST}}$ estimates were significant in L. obtusata.

Nei's unbiased genetic identities and distances were used to compare all combinations of pairs. The UPGMA tree of the genetic distances is shown in Fig. 2. The mean Nei genetic distance between the two species was 0.37 , with all the populations of each species clustered together. Moreover, the genetic similarities of each pair-wise comparison were not statistically different within species, using bootstrap similarity confidence intervals. This means that the $L$. mariae 'exposed' morph is genetically similar to the 'typical' morph of the species, and so the exposed morph may be included in L. mariae.

\section{Microgeographical analysis}

Tables of allelic frequencies of noncopulating $L$. mariae and $L$. obtusata, from the microgeographical study of Abelleira (July 1990), are available from the authors. No significant heterogeneity in allele frequencies was found between areas from the microgeographical study, and between them and previous samples of Abelleira (October 1989) from the geographical study. The fixation $F$ indices for the four areas of the microgeographical study are shown in Table 4 . The $F_{\text {Is }}$ per locus estimates differed greatly 
Table 3 Fixation $F$ indices for both Littorina mariae and L. obtusata in the Ria of Muros-Noya

\begin{tabular}{|c|c|c|c|c|c|c|}
\hline \multirow[b]{2}{*}{ Locus } & \multicolumn{3}{|c|}{ L. mariae } & \multicolumn{3}{|c|}{ L. obtusata } \\
\hline & $F_{\text {IS }}$ & $F_{\mathrm{IT}}$ & $F_{\mathrm{ST}}$ & $F_{\text {IS }}$ & $F_{\text {IT }}$ & $F_{\mathrm{ST}}$ \\
\hline$P g i$ & -0.070 & -0.020 & $0.046 * * *$ & -0.075 & -0.033 & $0.039 * * *$ \\
\hline$P g m$ & 0.119 & 0.151 & $0.037^{* * *}$ & 0.036 & 0.069 & $0.034^{* * * *}$ \\
\hline$M p i$ & - & - & - & 0.069 & 0.074 & 0.005 \\
\hline$E s-2$ & 0.068 & 0.107 & $0.042 * * *$ & 0.059 & 0.150 & $0.097 \stackrel{* * *}{=}$ \\
\hline$E s-c$ & 0.017 & 0.133 & 0.118 *** & -0.024 & 0.018 & $0.042 * * *$ \\
\hline$A p$ & - & - & - & -0.023 & -0.021 & 0.002 \\
\hline Ark & -0.017 & 0.001 & 0.018 ** & -0.005 & -0.002 & 0.004 \\
\hline Lap-1 & 0.154 & 0.250 & $0.114^{* * *}$ & 0.179 & 0.211 & $0.038^{* * *}$ \\
\hline Lap-2 & -0.115 & 0.026 & $0.127 \stackrel{* * *}{*}$ & -0.077 & -0.051 & $0.024^{*}$ \\
\hline Mean & 0.027 & 0.109 & 0.085 & 0.017 & 0.053 & 0.037 \\
\hline
\end{tabular}

A pseudoprobability $\chi^{2}$ homogeneity test (Zaykin \& Pudovkin, 1993) was used to estimate the significance of $F_{\mathrm{ST}}$. The underlined asterisks represent the significant cases following Bonferroni corrections. $(N)$ is sample size.

${ }^{*} P \leqslant 0.05,{ }^{* *} P \leqslant 0.01,{ }^{* * *} P \leqslant 0.001$.

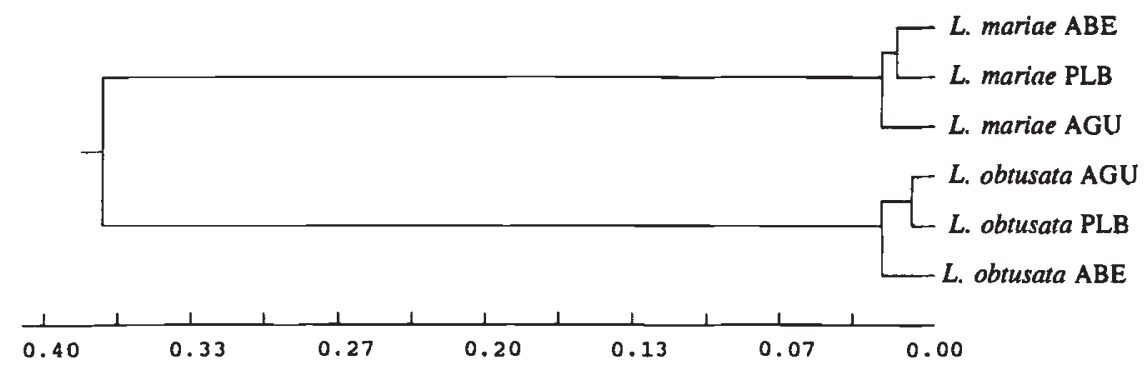

NEI GENETIC DISTANCE (D)
Fig. 2 UPGMA cluster analysis for the three populations of Littorina mariae and $L$. obtusata species, using the unbiased Nei genetic distance coefficient. between species, except for $E s-c, A p, L a p-1$ and Lap2 . In both species these $F_{\text {IS }}$ estimates were usually completely different from the $F_{\text {IS }}$ estimates for the geographical study. There was no significant $F_{\mathrm{ST}}$ estimate, after Bonferroni corrections, in $L$. mariae or in $L$. obtusata, even though the $F_{\mathrm{ST}}$ estimates per locus in $L$. obtusata were significantly greater than the $F_{\mathrm{ST}}$ estimates per locus in $L$. mariae ( $U=13, n_{1}=9, n_{2}=9$, $P<0.05)$. However, the sample size for $L$. obtusata was lower than for $L$. mariae in the four samples and this can fully explain the genetic structure differences at the microgeographical level (see Chakraborty \& Leimar, 1987).

\section{Discussion}

Natural populations of the sibling species $L$. mariae and $L$. obtusata showed different population subdivision and genetic variability in the Muros-Noya Ria. However, before discussing these data, the demo- graphic structure and the existence of heterozygote deficiences of the samples studied should be described.

The frequency of males and females was homogeneous whereas the frequency of old and young snails was heterogeneous among populations. The latter result was expected because the different samples were obtained in different seasons and years, and the frequency of age classes changes seasonally in these species (Goodwin \& Fish, 1977; Fretter \& Graham, 1980). However, these results do not affect the genetic analysis as there were no significant genetic differences between sex or age classes. In addition, the degree of genetic variability or population subdivision observed in $L$. mariae and $L$. obtusata, as well as the genetic distance estimate $(D=0.37)$ found between these species, was comparable to that found in other studies on these and similar species (see Ward, 1990; Zaslavskaya et al., 1992).

Only a few significant cases of heterozygote deficiencies were observed in the species studied, 
Table 4 Fixation $F$ indices for Littorina mariae and $L$. obtusata species in the microgeographical study (Abelleira)

\begin{tabular}{|c|c|c|c|c|c|c|}
\hline \multirow[b]{2}{*}{ Locus } & \multicolumn{3}{|c|}{ L. mariae } & \multicolumn{3}{|c|}{ L. obtusata } \\
\hline & $F_{\text {IS }}$ & $F_{I T}$ & $F_{\mathrm{ST}}$ & $F_{\text {IS }}$ & $F_{\mathrm{IT}}$ & $F_{\text {ST }}$ \\
\hline$P g i$ & 0.059 & 0.061 & 0.002 & -0.011 & -0.003 & 0.008 \\
\hline Pgm & -0.005 & -0.001 & 0.003 & 0.043 & 0.050 & 0.008 \\
\hline$M p i$ & 0.337 & 0.339 & 0.003 & -0.019 & -0.012 & 0.007 \\
\hline$E s-2$ & -0.007 & -0.004 & 0.003 & 0.091 & 0.112 & 0.023 \\
\hline$E s-c$ & 0.114 & 0.129 & $0.017^{* *}$ & 0.057 & 0.061 & 0.004 \\
\hline$A p$ & -0.020 & -0.013 & 0.007 & -0.027 & -0.010 & 0.016 \\
\hline Ark & 0.185 & 0.187 & 0.003 & -0.115 & -0.104 & 0.009 \\
\hline Lap-1 & 0.137 & 0.143 & 0.007 & 0.277 & 0.281 & 0.005 \\
\hline Lap-2 & -0.038 & -0.038 & 0.001 & -0.098 & -0.085 & 0.013 \\
\hline Mean & 0.098 & 0.104 & 0.007 & 0.014 & 0.025 & 0.011 \\
\hline
\end{tabular}

A pseudoprobability $\chi^{2}$ homogeneity test (Zaykin \& Pudovkin, 1993) was used to estimate the significance of $F_{\mathrm{ST}}$ (Workman \& Niswander, 1970). The underlined asterisks represent the significant cases following Bonferroni corrections. $(N)$ is sample size.

${ }^{* *} P \leqslant 0.01$.

mostly at the Lap-1 locus. This result agrees with similar studies on these and related littorinid species (see Ward, 1990). However, there are no causes that can be said with certainty to explain the particular behaviour of the Lap-1 locus (for a review of the causes, see Gaffney et al., 1990). Perhaps natural selection, in combination with habitat choice for the genotypes (or ecotypes) involved, can partially contribute to the heterozygote deficiencies in this locus (GarcíaDorado, 1986). More surprisingly, a significant association for the $F_{\text {Is }}$ per locus was found between the species in the geographical study, but not in the microgeographical study. However, it is difficult to interpret this result. Perhaps the significant heterozygote deficiency in Lap-1 in both species may explain the significant $F_{\text {IS }}$ association from the geographical study. In fact, the $F_{\text {IS }}$ per locus association between species is not significant if the Lap-1 locus is excluded from the analysis.

In the Muros-Noya Ria $L$. mariae showed greater genetic subdivision and lower genetic variability for the loci studied than $L$. obtusata (Table 3 ). These are rather surprising results because both species are supposed to have similar life history characteristics (Fretter \& Graham, 1980). The genetic variability result may be real (although it should be regarded with caution owing to the low number of loci studied) as most studies comparing heterozygosities between both sibling species found a similar trend (reviewed in Ward, 1990; Zaslavskaya et al., 1992). The biological and ecological similarities of $L$. mariae and $L$. obtusata in
Galician populations allows us to suggest which life history characters affect each species separately.

There are no direct estimates of the dispersal capabilities or migration rates in these species but laboratory observations regarding mobility of juveniles and adults, as well as female capability to store sperm (Rolán-Alvarez, 1992, 1993), suggest them to be similar. Other features, such as egg masses or juveniles rafting on seaweeds (Jokiel, 1990), if they exist, would be very similar because the species feed on the same algae in Galicia (Rolán \& Templado, 1987; RolánAlvarez, 1992). Moreover, L. mariae and L. obtusata have similar geographical distributions in the MurosNoya Ria (Fig. 1).

Natural selection has been claimed as an important factor producing population genetic differentiation but it is impossible to test all the potential ways of influencing this factor in natural populations (Kimura, 1983). Moreover, allozymic polymorphism appears to depend fundamentally on stochastic factors, even though a smaller part of the variability may be caused by natural selection (Kimura, 1983; Skibinski et al., 1993). Some ecological selective hypotheses have been claimed to explain allozymic polymorphism, but not genetic differentiation, in natural populations (reviewed in Kimura, 1983). Nevertheless, these selective hypotheses do not succesfully explain the results of this study, as $L$. obtusata and $L$. mariae have rather similar habitats and life histories on Galician shores. Moreover, it is very difficult to explain the differences between $L$. mariae and $L$. obtusata in heterozygosity 
and genetic differentiation, simultaneously, by any selective hypothesis. In addition, when different morphs or ecotypes are included in the analysis, natural selection may have, at least indirectly, a greater effect on the observed genetic polymorphism. The $L$. mariae PLB population illustrates a particular adaptation to a different habitat. Thus, following the selective argument, we would expect an important contribution from this population to the genetic subdivision in this species. However, we found the same pattern excluding the PLB samples from both species. These facts do not support the suggestion that natural selection is a major contributing factor causing differences in genetic structure between $L$. mariae and $L$. obtusata.

Every factor that influences the effective population size, by means of genetic drift, may also be responsible for the differences in genetic structure and variability between species (Kimura, 1983; Slatkin, 1987). Mating system is one of the most important life history characteristics that can influence the effective population size, but $L$. mariae and $L$. obtusata appear to display similar mating systems (Fretter \& Graham, 1980; RolánAlvarez, 1992). However, there are some differences in life histories that suggest different effective population sizes in each species. They appear to have similar population densities on Galician shores, although $L$. mariae has a lower population density during the winter (Rolán \& Templado, 1987; Rolán-Alvarez, 1993). Population bottlenecks or founder events have been used to explain reductions in heterozygosity level or genetic differentiation in natural populations (Berger, 1977; Ward, 1990), but the effectiveness of the process depends on the importance and the frequency of the bottlenecks as well as the rate of population recovery (Kimura, 1983; Nei, 1987). It would be necessary to assume significant bottlenecks every winter in $L$. mariae to explain the allozymic variability and genetic structure differences with respect to $L$. obtusata. Thus, this phenomenon may contribute to the species differences but it does not appear to be the only factor.

Hill (1972) showed that in dioecious organisms the effective population size depends on the number of males and females and the generation interval of the species. So, species with longer generation intervals will have larger effective population sizes and will be less affected by genetic drift (Hill, 1972; Kimura, 1983). The sex ratio was similar in all populations of the two species, but it is known that there are substantial differences between $L$. mariae and $L$. obtusata in the generation interval (Fretter \& Graham, 1980). A similar trend apparently occurs on Galician shores, with $L$. mariae mostly being annual and $L$. obtusata perennial (two to a few years) (Rolán-Alvarez, 1992). If it is assumed that $L$. mariae and $L$. obtusata have exactly the same life history characteristics apart from the generation interval, then because of this fact alone, they would show different genetic structures and heterozygosity levels (Hill, 1972).

The exact generation interval and population density through seasons are not known in $L$. mariae and L. obtusata on Galician coasts. Thus, further studies in natural populations, on longevity as well as population densities, are necessary before quantitative estimates of the contribution of these factors to the genetic structure in each species can be obtained.

\section{Acknowledgements}

We thank E. Rolán for introducing us to the evolutionary problems of these species. One of us (E. R-A) was supported by a fellowship from the Xunta de Galicia. We thank H. Quesada and C. Saavedra for helpful technical advice and theoretical discussions, and $\mathrm{K}$. Johannesson and A. Tatarenkov for constructive comments and corrections of an earlier version.

\section{References}

BERGER, E. M. 1977. Gene-enzyme variation in three sympatric species of Littorina. II. The Roscoff population, with a note on the origin of North American L. littorea. Biol. Bull., 153, 255-264.

BERGER, E. M. 1983. Population genetics of marine gastropods and bivalves. In: Wilbur, K. M. (ed.) The Mollusca, vol. 6, Ecology, pp. 563-596. Academic Press, New York.

CHAKRABORTY, R. AND LEIMAR, o. 1987. Genetic variation within a subdivided population. In: Ryman, N. and Utter, F. (eds) Population Genetics and Fishery Management, pp. 89-120. University of Washington Press, Washington.

FRETTER, v. AND GRAHAM, A. 1980. The prosobranch molluscs of Britain and Denmark. Part 5. Marine Littorinaceae. J. Moll. Stud., Suppl. 7, 243-284.

GAFFNEY, P. M., SCOTT, T. M., KOEHN, R. K. AND DIEHL, W. J. 1990. Interrelationships of heterozygosity, growth rate and heterozygote deficiencies in the coot clam, Mulinia lateralis. Genetics, 124, 687-699.

GARCIA-DORADO, A. 1986. The effect of niche preference on polymorphism protection in a heterogeneous environment. Evolution 40, 936-945.

GOODWIN, B. J. AND FISH, J. D. 1977. Inter and intra specific variation in L. obtusata and L. mariae. J. Moll. Stud., 43, 241-254.

HILL, W. G. 1972. Effective size of populations with overlapping generations. Theor. Pop. Biol., 3, 278-289.

JANSON, K. 1987a. Allozyme and shell variation in two marine snails (Littorina, Prosobranchia) with different dispersal abilities. Biol. J. Linn. Soc., 30, 245-256.

JANSON, K. 1987b. Genetic drift in small and recently founded populations of the marine snail Littorina saxatilis. Heredity, 58, 31-37. 
JOHANNESSON, K. AND JOHANNESSON, B. 1989. Differences in allele frequencies of $A a t$ between high- and mid-rocky shore populations of Littorina saxatilis Olivi suggest selection in this enzyme locus. Genet. Res., 54, 7-11.

JOHNSON, M. S. AND BLACK, R. 1991. Genetic subdivision of the intertidal snail Bembicium vittatum (Gastropoda: Littorinidae) varies with habitat in the Houtman Abrolhos Islands, Western Australia. Heredity, 67, 205-213.

JOKIEL, P. L. 1990. Long-distance dispersal by rafting: reemergence of an old hypothesis. Endeavour, 14, 66-73.

KIMURA, M. 1983. The Neutral Theory of Molecular Evolution. Cambridge University Press, Cambridge.

KNIGHT, A. J., HUGHES, R. N. AND WARD, R. D. 1987. A striking example of the founder effect in the mollusc Littorina saxatilis. Biol. J. Linn. Soc., 32, 417-426.

LEWONTIN, R. C. 1991. Twenty-five years ago in genetics: electrophoresis in the development of evolutionary genetics: milestone or millstone? Genetics, 128, 657-662.

MORRIS, S. R. 1979. Genetic Variation in the Genus Littorina. Ph.D. Thesis, University of Wales.

NEI, M. 1987. Molecular Evolutionary Genetics. Columbia University Press, New York.

QUESADA, H. 1992. Genetic Structure of Natural Populations of the Mussel Mytilus galloprovincialis. Ph.D. Thesis, University of Santiago de Compostela, Spain (in Spanish).

QUESADA, H., SANJUAN, J. AND SANJUAN, A. 1992. GENET2: a basic program for the analysis of deviations from Hardy-Weinberg law. J. Hered., 83, 460-461.

REID, D. 1990. Note on the discrimination of females of Littorina mariae Sacchi and Rastelli and L. obtusata (Linnaeus). J. Moll. Stud., 56, 113-114.

RICE, W. R. 1989. Analysing tables of statistical tests. Evolution, 43, 223-225.

ROBERTSON, A. AND HILL, W. G. 1984. Deviations from Hardy-Weinberg proportions: sampling variances used in estimation of inbreeding coefficients. Genetics, 107, 703-718.

ROLAN, E. AND TEMPLADO, J. 1987. Consideraciones sobre el complejo Littorina obtusata-mariae (Mollusca, Gastropoda, Littorinidae) en el Noroeste de la península Ibérica. Thalassas, 5, 71-85.

ROLAN-ALVAREZ, E. 1992. A method of breeding L. obtusata (L.) and L. mariae Sacchi and Rastelli: preliminary results. In: Grahame, J., Mill, P. and Reid, D. (eds) Proceedings of the Third International Symposium on Littorinid Biology, pp. 163-168. The Malacological Society of London, London.

rolan-ALVAREZ, E. 1993. Genetic Structure and Sexual Selection in Natural Populations of Two Sibling Species of the Genus Littorina. Ph.D. Thesis, University of Santiago de Compostela, Spain (in Spanish).

SERGIEVSKY, S. O. 1985. Populational approach to the analysis of the periwinkle Littorina obtusata (L.) invasions with the trematode parthenitae. Helminthologia, 22, 5-14.

SKIBINSKI, D. O. F., WOODWARK, M. AND WARD, R. D. 1993. A quantitative test of the neutral theory using pooled allozyme data. Genetics, 135, 233-248.

SLATKIN, M. 1987. Gene flow and the geographic structure of natural populations. Science, 236, 787-792.

SWOFFORD, D. L. AND SELANDER, R. B. 1981. Program for the comprehensive analysis of electrophoretic data in population genetics and systematics. J. Hered., 72, 281-283.

WARD, R. D. 1990 . Biochemical genetic variation in the genus Littorina (Prosobranchia: Mollusca). Hydrobiologia, 193, 53-69.

WARD, R. D. AND WARWICK, T. 1980. Genetic differentiation in the molluscan species Littorina rudis and Littorina arcana (Prosobranchia: Littorinidae). Biol. J. Linn. Soc., 14, 417-428.

WILliams, G. A. 1990. Littorina mariae - a factor structuring low shore communities? Hydrobiologia, 193, 139-146.

WILliams, G. A. 1992. The effect of predation on the life histories of Littorina obtusata and L. mariae. J. Mar. Biol. Ass. U.K., 72, 403-416.

WOLF, K. 1991. Analysis of allozyme variability in three Plantago species and a comparison of morphological variability. Theor. Appl. Genet., 81, 119-126.

WORKMAN, P. L. AND NISWANDER, J. D. 1970. Population studies on Southwestern Indian tribes. II. Local genetic differentiation in the Papago. Am. J. Hum. Genet., 22, 24-49.

WRIGHT, s. 1978. Evolution and the Genetics of Populations, vol. 4. Variability within and among National Populations. University of Chicago Press, Chicago.

ZASLAVSKAYA, N. I., SERGIEVSKY, S. O. AND TATARENKOV, A. N. 1992. Allozyme similarity of Atlantic and Pacific species of Littorina (Gastropoda: Littorinidae). J. Moll. Stud., 58, 377-384.

ZAYKIN, D. V. AND PUDOVKIN, A. I. 1993. Two programs to estimate significance of $\chi^{2}$ values using pseudo-probability tests. J. Hered., 84, 152. 